\title{
Cultural Change in the Context of Implementing Online Learning in Higher Education
}

\author{
Weni Rosdiana* \\ Department of Public Administration \\ Faculty of Social Sciences and Law \\ Universitas Negeri Surabaya \\ Surabaya, Indonesia \\ wenirosdiana@unesa.ac.id
}

Gading Gamaputra

Department of Public Administration

Faculty of Social Sciences and Law

Universitas Negeri Surabaya

Surabaya, Indonesia

gadinggamaputra@unesa.ac.id

\author{
Dian Arlupi Utami \\ Department of Public Administration \\ Faculty of Social Sciences and Law \\ Universitas Negeri Surabaya \\ Surabaya, Indonesia \\ dianarlupi@unesa.ac.id
}

\author{
Yuni Lestari \\ Department of Public Administration \\ Faculty of Social Sciences and Law \\ Universitas Negeri Surabaya \\ Surabaya, Indonesia \\ yunilestari@unesa.ac.id
}

\begin{abstract}
This paper will describe efforts to change the culture of online learning in higher education in Indonesia amid the Covid-19 epidemic which includes approaches to cultural change that need to be carried out by all academic communities in higher education. An Approach to cultural change is done through a behavioral approach, structural approach and technological approach. As for the success of the change can be achieved if there is a need to use online learning, support ideas to solve problems online learning the adoption and implementation process that requires lecturers and students to do online learning with support of the availability of modules / tutorials and the freedom to determine online media used in learning with adequate resource support.
\end{abstract}

Keywords: cultural change, online learning, higher education

\section{INTRODUCTION}

Education is an effort to improve the quality of human life, namely people who have competence and productive . One's competence is built on the knowledge and skills gained through the educational process. The education process is a dynamic and challenging activity. Education will always change along with changing times, because it involves situations and conditions that occur and the needs of life in the future. So, education always require improvement and increase in line with the circumstances that are running and the higher needs and guidance of people's lives. Technology has affected the use of the system and media of learning used by some educational institutions in order to support the achievement of learning.

Pendemi Covid-19 that occurred in Indonesia led to the Indonesian Government issued a number of policies in the field of education in eradicating pendemic Covid-19. The cause of the spread of this virus is from human to human, so it is necessary to do social restrictions in interacting and activities. One of them is study from home or studying at home as a consequence of appeals for social restrictions. Goverment head and university leaders move quickly to make a decision to set learning policies at home during Covid pemdemi-19 to reduce the risk of a greater spread of the virus. Study from home policy is directed towards using online learning. Situations and conditions that do not allow face-to-face learning have forced the academic community both lecturers and students to do online learning. Learning is carried out using various online learning media in the form of e-book references, learning videos, virtual learning and other forms.

Online learning is an education processthat takes place over the Internet,with the teacher and student separated geographically, using a webbased educational delivery system that includes software to provide a structured learning environment. It may be synchronous (communication in which participant interact in real time, such as online video) or a synchronous (communication) separated by time, such as email or online discussion forums). It may be accessed from multiple setting (in school andor out of school buildings).

Besides online lerning there is virtual learning. According Wilson oppinion that virtual learning environment (VLE) is defined as a computer/technologybased environment which is moderately opening systems, allowing communications and information sharing with other participants and instructors' and providing access to a wide range of assets and resources[1]. The significance of a VLE is to entirely bring out the characteristics of both 'Learning Anywhere and Anytime', ie, learning in an asynchronous manner. Hill \& Hannafin said that the principle of a VLE is to underline on self-control, disperse thinking models, diverse viewpoints, and free-thinking[2].

Characteristics of virtual learning is indicated by a separate position between educators and learners, learning systems provide open access even give you the freedom to choose a variety of learning resources and based learning network. In addition, Department of National Education explained learning by utilizing the internet will encourage the growth of student learning skills (learning how to learn), reasoning skills (higher order thinking skills), communication skills (oral and written), the ability to find a variety of learning resources, increase student activity, and improve skills social[3]. Anderson suggested that by 
providing opportunities for students to interact with various learning resources available through the Internet, students' skills in lifelong learning will improve and through online discussions students will master responsible and professional communication skills[4].

Online learning offers various facilities for learning. However, it is also necessary to know the various potential problems that arise in online learning. These problems include the following;

a. The problem of access to the Internet, especially in geographically remote areas and communities with low socio-economic levels.

b. Demand all students to be responsible for the learning process.

c. In asynchronous online learning, feedback may be delivered after more than an hour or even days.

d. Demand training and technical assistance for both lecturers and students as well as learning design support during the development of concepts and subjects that will be presented online.

e. There is no quality control mechanism to ensure that information available on the Internet is accurate and without bias[5].

f. Information technology cannot replace the presence of educators in mentoring interactions.

g. Online learning has not been very effective in achieving productive skills and attitude development.

Organizational culture according to Schein[6] defines culture as "A pattern of shared basic assumptions that the group has learned as it solved its problems of external adaptation and internal integration that has worked well enough to be considered valid and therefore, to be taught to new members as the correct way to perceive, think, and feel in relation to those problems". As groups evolve over time, they face two basic challenges: integrating individuals into an effective whole, and adapting effectively to the external environment in order to survive. As groups find solutions to these problems over time, they engage in a kind of collective learning that creates the set of shared assumptions and beliefs that we call culture. According to the Schein, organizational culture is the result of group experiences, which is to a large extent, unconscious[6]. He claims that culture is largely an invisible influence factor. It functions in a way that members of live organizations have their values and actions in their routines without consciously thinking about them. This aspect becomes interesting for the question if and how culture can be manipulated or influenced. Especially as the assumptions are invisible and unconscious, whereas rituals, values and symbols can be partly be explicit. Organizational culture is the response to the challenges and the organization has and fulfills its purposes.

This paper will describe efforts to change the culture of online learning in universities in Indonesia amid the Covid19 epidemic which includes approaches to cultural change that need to be carried out by all academic communities in higher education.

\section{METHOD}

This research method used is descriptive qualitative to describe the approach in changing online learning culture and the factors that support the success of changing online learning culture. Data collection techniques are through literature study and observation. And using qualitative data analysis.

\section{RESUlTS AND DISCUSSION}

Gordon introduces three approaches that can be used in order to change organizational culture, namely the behavioral approach, the structural approach and the technological approach[7]. So that, in the context of changing the culture of online learning in higher education, the following approaches can be used;

\section{a. Behavioral Approach.}

This approach expects behavioral change for teachers and students to learn online during the Covid-19 epidemic. This change in behavior brings the consequences of teachers and students can use various learning applications online. Online communication is done by looking at ethics in online learning. Students must be responsible and full of honesty in following lecture material as well as doing assignments and exam questions. Students will succeed in learning if students have high motivation to learn, the ability to learn independently, and self-discipline to participate actively in learning . Self-directed learning is often understood to be a generic term for all forms of learning in which the learners can determine and be responsible for their learning processes including tasks, methods and amount of time invested themselves (and/or take part in the decision) (Deitering 1996)[8]. Friedrich and Mandl clarify the difference between "self-responsibility" and "self-directing" in the following way: Self-directed learning offers learners the possibility to determine on their own what to learn and what to aim for their learning is to be. Self-directed learning contains the option for learners to be responsible for their way of learning, regulating their learning (how? When?) When learning contents and aims are pre-determined[9].

Whereas the instructor in online learning plays more a role as a facilitator of the student learning process (the process facilitator), the advisor and counselor (the advisorcounselor), the assessor, the researcher, the facilitator for the mastery of learning material by students (the content facilitator), technology experts (the technologist), designer of learning (the designer), and administrator-manager (the manager-administrator).

b. Structural approach (through changes in organizational structure and strategy).

This approach makes changes to the organizational structure and strategy through efforts to redesign the organizational structure and strategy in accordance with the current situation. online learning systems need to make changes in learning activities which include design, implementation and evaluation. In addition, a change in strategy was also made, for example, some student academic services that are usually done manually were changed using online services. The service is provided to support the 
success of student learning such as the provision of catalogs, schedules, registration, bookstores, value announcements, grade transcripts, counseling guidance, tutorials, laboratories, libraries, and so on. The service can be performed by internal units within the institution concerned or outside parties. Utilize outsiders, for example in collaboration with online bookstores in the supply of study materials or expert technicians from other institutions for handling online techniques. Therefore, collaboration is the key to the success of integrating virtual learning into faceto-face learning. With the use of internal and external resources, new administrative procedures are needed or even new organizational structures need to be developed[10]. In addition to changing organizational structures, Levy suggests five other factors that need to be considered in designing distance learning programs through online[10]. The five factors are vision and planning, curriculum, staff training and support, student services, student training and support, and copyright and intellectual property.

\section{c. Technological Approach.}

This approach changes the equipment, methods, and learning techniques. This change needs to be supported by adequate facilities and infrastructure to support the implementation of online learning. For example, universities provide online learning tools through elearning, v-learning. You can also use email, chat, google classroom and so on. To subscribe to the application for meetings and provide internet quota subsidies for lecturers and students. In addition, students are also required to have basic skills in virtual learning, such as the use of computermediated technology, online social skills, online ethics, web navigation, and web search (McPherson \& Nunes, 2004). According to Nunes et al. (McPherson \& Nunes, 2004) these skills are called networked information and communication literacy skills (NICLS). NICLS is a skill needed by students to succeed in learning by using information and communication technology. According to McPherson \& Nunes (2004) NICLS consists of computer-mediated communication (CMC) communication skills and information skills. CMC skills are related to student interaction with the learning community. Meanwhile, information skills are related to issues of information anxiety and excessive workload, as well as access to learning resources.

Changes the paradigm of learning online have to be followed by changes in operational systems of work and organizational structure, as well as literacy Technology information and communication , Herrington (2001) stated that the competence or ability of the user, the support means, and the adequacy of infrastructure are the factors that determine the effectiveness of virtual learning in learning . Daft (1995) proposes 5(five) key elements for successful change. For this reason, the success of changing the online learning culture in higher education will be determined by the following :

\section{a. Needs - Needs to Change.}

College leaders and all academics consider that online learning is needed as a substitute for conventional learning that has been done so far. Disaster situations such as the
Covd-19 current situation have forced all academics to choose online learning. So that learning activities can be carried out with different methods. To support the implementation of online learning, facilities and infrastructure need to be supported.

\section{b. Ideas - Ideas for Change.}

Ideas are needed for change for the better. Changes to the system and strategies need to be made to solve existing measures. Follow-up on complaints, problems and complaints must be done immediately by synergizing the resources they have. Changes can be made to various input problems and alternative mass solutions related to online learning.

\section{c. Adoption.}

The adoption process can be immediately carried out after it was agreed the need for changes in online learning to replace conventional learning. Massive and ongoing socialization must be carried out with rapid intensity and frequency. The term Learning by doing is a picture that can represent the efforts made by the entire academic community to support the implementation and success of online learning.

\section{d. Implementation}

The implementation phase of online learning makes it easy for the academic community to choose a platform that allows and makes it easier to support the smooth online learning. Lecturers and students can agree on the choice of platform to be used. Platforms that can be chosen include Whatsapps, Googlemeet, Googleclassroom, V Learning, Zoom and others. In the implementation of online learning, monitoring and online learning are also carried out covering the preparation, implementation and evaluation stages of learning.

\section{e. Resources}

Resource support is needed in conducting online defenses Resources can include people, budgets and facilities. Human resources, namely the support of lecturer and student competencies in the use of technology and the internet in learning. For that we need the availability of internet package support in supporting online learning activities. Therefore, the university provides internet data packages or the like so that students can still participate in online learning without difficulty.

Lecturer competencies in online learning in addition to being able to master course material and learning skills are also required to master the skills of using information and communication technology to manage and facilitate online learning . Berge suggests four main roles of online tutors namely Pedagogical/ Intellectual, Social, Managerial/ Organizational, and Technical Roles[11];

\section{a. Pedagogical / intellectual roles}

This role must be possessed by the lecturer in encouraging students to be actively involved in discussion activities about the study material or lecture material and the skills that students must master as learning outputs. In carrying out this role, lecturers are expected to be skilled in opening discussions, focusing students on the material and 
topics discussed, intervening in discussions to encourage interesting and productive talks, helping and maintaining student involvement in discussions, and summarizing the results of discussions.

\section{b. Social roles}

This role expects lecturers to create and develop a friendly and pleasant learning environment so that students feel confident that they can master the expected learning messages.

\section{c. Managerial/organizational roles}

This role expects lecturers to have the ability to set learning goals, design learning activities, arrange learning activities schedules and assignments, and explain procedural rules and norms for decision making and supervision of the learning process and outcomes.

\section{d. Technical roles}

This role expects professors to get to know, comfortable, and system and software control of information and communication technologies that make up the online learning environment.

\section{CONCLUSIONS AND SUGGESTIONS}

Approaches in adjusting changes to online learning culture include structural changes through changes in plans, implementation and evaluation of online-based learning. In addition, efforts to adjust changes in independent learning behavior with various learning resources available online as well as technological changes that support the smoothness and ease of online learning. Successful changes in online learning culture can be achieved through encouraging the need to switch online learning from conventional learning, support ideas to solve problems/barriers to online learning, the process of adopting learning through the availability of tutorials/modules using online media, implementation of online learning makes it easy for lecturers and students to choose the platform used in the learning process and the availability of sufficient resources.

\section{REFERENCES}

[1] M. Matthews, "Virtual learning environments," Subj. Libr. Engag. with Learn. Teach. Environ., vol. 2, no. 4, pp. 79-88, 2012.

[2] J. R. Hill and M. J. Hannafin, Cognitive Strategies and Learning from the World Wide Web. 1997.

[3] Departemen Pendidikan Nasional, Peningkatan Kualitas Pembelajaran. Jakarta: Dit. P2TK dan KPT, Ditjen. Dikti, Depdiknas., 2004.

[4] A. Herrington and J. Herrington, Authentic learning environments in higher education By Herrington, Tony \& Herrington, Jan, vol. 39, no. 4. 2008.

[5] M. Simonson, S. Smaldino, M. Albright, and S. Zvacek, Teaching and Learning at a Distance: Foundations of Distance Education (2nd Ed.). New Jersey: Merill Prentice Hall., 2003.

[6] E. H. Schein, Organizational Culture and Leadership, 2nd ed. San Francisco: Jossey-Bass, San-Francisco, CA., 1992.

[7] A. J. Reilly, "Three Approaches to Organization Learning," Pfeiffer Libr., vol. 16, no. 2, pp. 21-25, 1998.

[8] A. Alberto, "Understanding Quality Culture in Assuring Learning at Higher Education Institutions," SSRN Electron. J., vol. 3, pp. 79-92, 2016.

[9] C. Gräsel, F. Fischer, and H. Mandl, "The Use of Additional Information in Problem-Oriented Learning Environments," Learn. Environ. Res., vol. 3, no. 3, pp. 287-305, 2000.

[10] S. Levy, "Six Factors to Consider when Planning Online Distance Learning Programs in Higher Education," Online J. Distance Learn. Adm., vol. VI, no. 1, 2003.

[11] M. McPherson and M. Baptista Nunes, Developing Innovation in Online Learning: An Action Research Framework. London: Routledge Falmer, 2004. 